\title{
PENCEMARAN SODIUM DODECYLBENZENE SULFONATE (SDBS) PADA IKAN AIR TAWAR: PENENTUAN AKUMULASI DAN MONITORING PENCEMARAN
}

\section{CONTAMINATION OF SODIUM DODECYLBENZENE SULFONATE (SDBS) IN FRESHWATER FISH: DETERMINATION OF ACCUMULATION, AND CONTAMINATION MONITORING}

\author{
Monica Cahyaning Ratri* \\ Program Studi Pendidikan Kimia, Universitas Sanata Dharma, Kampus III Universitas Sanata \\ Dharma, Paingan, Maguwoharjo, Yogyakarta, 55282
}

Received February 24, 2017; Accepted March 30, 2017

\begin{abstract}
The research for accumulation determination and monitoring of Sodium Dodecylbenzene Sulfonate (SDBS) contamination in freshwater fish has been conducted. The aims of this research were to determine the interference of protein and ions in analysis, the parameters of validation, the correlation of SDBS concentration in the basin and SDBS accumulation in catfish followed by SDBS analysis in freshwater fish that sold in market in the area of Yogyakarta city. This research was started by isolating SDBS from freshwater fish using soxhlet extraction method and then followed by analysis of SDBS using spectrophotometer UV-Vis with acridine orange (AO) reagent. The results showed that the presence of proteins might be interferre the analysis process, $\mathrm{Ca}^{2+}$ and $\mathrm{Mg}^{2+}$ ions might interfere the analysis process at concentrations $>12 \mathrm{mg} / \mathrm{L}$ and $>6$ $\mathrm{mg} / \mathrm{L}$. Analytical method validation was performed and showed correlation coefficient values $(r)$ was 0,9981, limit of detection was $0,089 \mathrm{mg} / \mathrm{L}$, limit of quantification was $0,0296 \mathrm{mg} / \mathrm{L}, \mathrm{RSD}<$ $2 \%$ and \% recovery between $83-107 \%$. The content of the SDBS in fish increased with increasing concentrations of SDBS in water and caused the decrease of Bio-concentration Factor (BCF) value. The concentration of SDBS in the analysis of fish in the market were between 0,00120,0029 $\mathrm{mg} / \mathrm{g}, 0,0038-0,0077 \mathrm{mg} / \mathrm{g}$ and 0.0008-0,0026 $\mathrm{mg} / \mathrm{g}$ for catfish, red tilapia and carp, respectively.
\end{abstract}

Keywords: accumulation, analysis, SDBS, freshwater fish

\section{ABSTRAK}

Penentuan akumulasi dan monitoring pencemaran Sodium Dodecylbenzene Sulfonate (SDBS) pada ikan air tawar telah dilakukan. Penelitian ini bertujuan untuk menentukan interferensi protein dan ion pada analisis, parameter validasi, hubungan konsentrasi SDBS dalam kolam dan akumulasi SDBS dalam ikan lele diikuti dengan analisis SDBS pada ikan air tawar yang dijual di pasar daerah kota Yogyakarta. Penelitian ini diawali dengan isolasi SDBS dari ikan air tawar dengan metode ekstraksi soxhlet yang dilanjutkan dengan analisis SDBS menggunakan spektrofotometer UV-Vis dengan pereaksi acridine orange (AO). Hasil penelitian menunjukkan bahwa adanya protein mengganggu proses analisis, ion $\mathrm{Ca}^{2+}$ dan $\mathrm{Mg}^{2+}$ dapat menginterferensi pada konsentrasi $>12 \mathrm{mg} / \mathrm{L}$ dan $>6 \mathrm{mg} / \mathrm{L}$. Validasi metode menunjukkan nilai koefisien korelasi (r) 0,9981, batas deteksi: 0,089 mg/L, batas kuantifikasi: 0,0296 mg/L, RSD < 2\% dan \% perolehan kembali antara 83-107\%. Kandungan SDBS dalam ikan meningkat seiring dengan meningkatnya konsentrasi SDBS di dalam air dan menyebabkan penurunan nilai Bioconcentration Factor (BCF). Konsentrasi SDBS dalam ikan pasar masing-masing antara 0,0012-

*Corresponding author: Monica Cahyaning Ratri

Email: monicacr.mcr@gmail.com 
0,0029 mg/g, 0,0038-0,0077 mg/g dan 0,0008-0,0026 mg/g, untuk ikan lele, nila merah dan gurame.

Kata kunci: akumulasi, Analisis, SDBS, Ikan air tawar

\section{PENDAHULUAN}

Ikan merupakan salah satu bahan makanan yang mengandung senyawa-senyawa fungsional yang bermanfaat bagi kesehatan seperti protein, peptida, vitamin dan mineral (Susanto dan Fahmi, 2012). Konsumsi ikan di Indonesia mengalami peningkatan sebesar 49,68\% pada tahun 2007-2009 yaitu sebesar 3.193.565 juta ton menjadi 4.780 .100 juta ton (Indradjaja, 2010). Jenis ikan yang paling banyak dikonsumsi adalah ikan lele yaitu sebesar 200.000 juta ton per tahun. Oleh karena itu keamanan ikan yang dikonsumsi oleh manusia harus diperhatikan. Di Indonesia budidaya ikan banyak dilakukan di aliran sungai dan waduk dengan menggunakan sistem keramba jaring apung (Ardi, 2013; Muhamat dan Hidayaturrahman, 2017). Sungai dan waduk merupakan jalur yang dilalui air limbah yang berasal dari rumah tangga sebelum akhirnya bermuara ke laut. Salah satu jenis limbah yang banyak dihasilkan oleh rumah tangga adalah limbah detergen. Penggunaan detergen hampir merata di semua tingkat masyarakat, meskipun demikian pengolahan terhadap limbah detergen tidak diperhatikan dengan baik. Pembuangan limbah detergen tanpa diproses dan tidak diolah dengan baik dapat mencemari lingkungan perairan. Menurut data dari laporan Revision of Ecolabel Criteria for Laundry Detergents (Arendorf et al., 2014), penggunaan berbagai jenis detergen di Eropa pada tahun 2013 mencapai 16 juta ton. Penggunaan detergen dengan jumlah yang besar akan sebanding dengan jumlah limbah yang dihasilkan. Detergen yang beredar di masyarakat mengandung bahan aktif yang berfungsi untuk mengikat dan menghilangkan kotoran. Bahan aktif yang terdapat pada detergen tersebut adalah surfaktan. Surfaktan anionik adalah surfaktan yang banyak dipergunakan. Bagian dari surfaktan anionik yang banyak dipergunakan sebagai bahan aktif detergen adalah Linear Alkylbenzene Sulfonate (LAS) dengan jenis Sodium Dodecyl Benzene Sulfonate (SDBS) (Rust dan Wildes, 2008; Schmitt, 2001).

SDBS merupakan jenis surfaktan anionik yang mempunyai gugus nonpolar berupa rantai alkil panjang dan gugus benzena yang bermuatan negatif dan bersifat hidrofobik. Gugus alkil panjang yang bersifat nonpolar mempunyai kecenderungan untuk terakumulasi di dalam tubuh (Britton, 1998). Gugus benzena yang juga bersifat nonpolar mempunyai sifat yang stabil sehingga sulit untuk terdegradasi (Graziano, 1999). Struktur SDBS yang banyak mempunyai komponen nonpolar dan bersifat hidrofobik berbahaya bagi makhluk hidup, khususnya makhluk hidup air yang hidup di perairan yang mengandung SDBS. Konsentrasi LAS dibawah 1,00 $\mathrm{mg} / \mathrm{L}$ dapat menyebabkan kerusakan jaringan pada hewan invertebrata yang hidup di air tawar (Coelho dan Rocha, 2010). LAS juga dapat terakumulasi pada sampel ikan Corbicula fluminea (Versteeg dan Rawlings, 2003), Pimephales promelas (Tolls et al., 1999), dan berbagai jenis ikan laut (Sáez et al., 2000). Berdasarkan sifat dan efek negatif yang dapat ditimbulkan LAS maka menurut (Dietrich, 2015) konsentrasi maksimum LAS yang diperbolehkan ada di dalam air minum adalah sebesar $0,5 \mathrm{mg} / \mathrm{L}$ dan $1 \mathrm{mg} / \mathrm{L}$ untuk keperluan lain.

LAS mempunyai komponen hidrofobik yang berpotensi masuk pada jaringan lemak dan terakumulasi (Britton, 1998). Surfaktan ionik juga dapat mendenaturasi protein sehingga protein di dalam tubuh makhluk hidup mengalami kerusakan (Otzen, 2011). Potensi LAS masuk dan terakumulasi di dalam tubuh makhluk hidup disebabkan karena konsumsi air minum yang tercemar atau berasal dari bahan makanan yang mengandung 
LAS. Apabila LAS tersebut tidak terdegradasi maka efek toksiknya meningkat pada rantai makanan (Britton, 1998).

Analisis surfaktan pada tubuh makhluk hidup telah dilakukan dengan berbagai metode, diantaranya adalah analisis Nonylphenol (NP) pada Juvenile yellowtail (Seriola lalandi) dengan menggunakan GC (Gassel et al., 2013). Analisis surfaktan pada ikan dapat dilakukan dengan menggunakan HPLC (Tolls, Haller, dan Sijm 1999; Sáez et al., 2000). Surfaktan SDBS juga dapat dianalisis dengan menggunakan Metylen blue (MB) dengan alat spektrofotometer (Muzakar, 2016).

Pada penelitian ini akan dilakukan analisis terhadap kandungan surfaktan anionik LAS jenis SDBS dengan menggunakan spektrofotometer UV-Vis dengan pereaksi acridine orange (AO). Analisis dilakukan untuk memonitoring kandungan SDBS pada ikan air tawar yang dijual di pasar di kota Yogyakarta. Pemilihan alat dan pereaksi ini disebabkan karena alat spektrofotometer UVVis mudah diijumpai dan analisis menggunakan pereaksi AO menggunakan bahan-bahan yang relatif aman bagi lingkungan serta memiliki parameter validasi yang baik.

\section{METODE PENELITIAN Bahan}

Surfaktan sodium dodecylbenzene sulfonate (SDBS) dan acridine orange [3,6-bis (dimethylamino) acridine] diperoleh dari Sigma Aldrich. Toluena, metanol, asam asetat glasial, etanol, n-heksana, isopropil alkohol, asam nitrat dan asam perklorat diperoleh dari E-merck, semua bahan dengan kualitas pro analisis. Sampel ikan lele yang dibudidaya secara terkontrol. Sampel ikan lain diambil dari beberapa pasar di kota Yogyakarta.

Alat

Spektrofotometer serapan atom (Perkin Elmer), soxhlet, corong pisah, spektrofotometer UV-Vis (Cintra GBC 2020), kertas saring, blender, rotary evaporator Buchi (CH-9230 flawil/schweiz), freeze dryer, lemari pendingin, timbangan analitik, $\mathrm{pH}$ meter (Toa).

\section{Budidaya ikan lele}

Budidaya ikan lele dilakukan di kolam fiber selama tiga bulan. Sebelum penyebaran bibit ikan lele, kolam fiber dipersiapkan terlebih dahulu. Persiapannya adalah dengan mengisi kolam fiber dengan air sebanyak 140 L pada setiap kolam, air pada kolam didiamkan selama 5 hari sebelum ditaburi benih ikan lele. Pada hari keenam bibit ikan lele dengan pajang 5-7 $\mathrm{cm}$ disebar ke dalam kolam fiber dengan kepadatan 30 ekor setiap kolam fiber. Bibit ikan dibiarkan beradaptasi selama 5 hari sebelum air kolam diberi surfaktan. Ikan lele diberi makan sebanyak dua kali sehari setiap pagi dan sore dengan menggunakan pelet ikan. Ikan lele kemudian dibudidayakan di dalam air kolam tergenang yang mengandung surfaktan. Air yang berada di kolam fiber diganti setiap 5 hari sekali. Konsentrasi surfaktan yang dipaparkan dibuat tetap pada masing-masing kolam yaitu sebesar 0; 2,5; 5; 10 dan $15 \mathrm{mg} / \mathrm{L}$. Sampel ikan lele diambil setelah tiga bulan proses budidaya. Pengambilan sampel dilakukan tiga kali pengambilan pada masing-masing kolam secara acak. Ikan diambil sebanyak dua ekor setiap kali pengambilan pada masing-masing kolam.

\section{Penentuan pengaruh protein terhadap analisis SDBS dalam tubuh ikan}

Penentuan pengaruh protein dilarutkan dengan melarutkan 0,1004 g Bovine Serum Albumin (BSA) ke dalam air hingga konsentrasi $1000 \mathrm{mg} / \mathrm{L}$. Larutan BSA 1000 $\mathrm{mg} / \mathrm{L}$ dengan volume tertentu dicampurkan dengan 1,20 mL larutan standar SDBS 100 $\mathrm{mg} / \mathrm{L}$ dan diencerkan hingga volume $50,0 \mathrm{~mL}$. Pengenceran dilakukan agar didapatkan konsentrasi BSA dalam larutan sebesar 5,00; 10,0; 50,0 dan $100 \mathrm{mg} / \mathrm{L}$. Sampel kemudian dianalisis melalui proses ekstraksi dalam kondisi optimum dan didapatkan absorbansi. Pengaruh protein ditentukan berdasarkan absorbansi yang terbaca.

\section{Penentuan pengaruh ion terhadap analisis SDBS dalam tubuh ikan}

Penentuan pengaruh ion dilarutkan dengan menambahkan larutan standar ion 
$1000 \mathrm{mg} / \mathrm{L}$ dengan volume tertentu dengan $1,20 \mathrm{~mL}$ larutan standar SDBS $100 \mathrm{mg} / \mathrm{L}$ dan diencerkan hingga volume $50,0 \mathrm{~mL}$. Pengenceran dilakukan agar didapatkan konsentrasi ion $\mathrm{Ca}^{2+}$ dalam larutan sebesar 0; 3,$00 ; 6,00 ; 9,00 ; 12,0$ dan $15 \mathrm{mg} / \mathrm{L}$. Sampel kemudian dianalisis melalui proses ekstraksi dalam kondisi optimum dan didapatkan absorbansi. Hal yang sama dilakukan padan ion $\mathrm{Mg}^{2+}$ pada konsentrasi $0 ; 2,00 ; 4,00$; 6,$00 ; 8,00$ dan 10,0 $\mathrm{mg} / \mathrm{L}$. Pengaruh ion ditentukan berdasarkan absorbansi yang terbaca.

\section{Penentuan parameter validasi metode Pembuatan kurva standar}

Pembuatan kurva standar dilakukan dengan membuat satu seri larutan standar berbagai konsentrasi diukur absorbansinya pada panjang gelombang optimum yaitu 499 nm. Kurva standar dibuat sesuai dengan prosedur penentuan linearitas. Variasi konsentrasi larutan standar yang dipakai adalah 0,$400 ; 0,800 ; 1,60 ; 3,20 ; 4,00$ dan 6,00 $\mathrm{mg} / \mathrm{L}$.

\section{Penentuan presisi intraday dan interday}

Penentuan presisi diwakili oleh konsentrasi rendah, sedang dan tinngi yaitu: 0,$4 ; 2,4 ; 6 \mathrm{mg} / \mathrm{L}$. Dilakukan tiga kali pengulangan disetiap konsentrasi pada hari yang sama dan tiga kali pengulangan pada hari yang berbeda.

\section{Penentuan persen perolehan kembali (akurasi)}

Penentuan akurasi dilakukan dengan mengisolasi SDBS dari ikan lele dengan metode ekstraksi Soxhlet. Sebanyak 18 ekor ikan diambil dari kolam budidaya dengan paparan SDBS $0 \mathrm{mg} / \mathrm{L}$. Ikan dipisahkan menjadi 3 bagian, 6 ekor ikan tiap bagian. Ikan lalu dipotong kecil dan dihaluskan dengan blender. Sampel ikan yang telah halus di spike dengan standar SDBS dengan konsentrasi $100 \mathrm{mg} / \mathrm{L}$ dengan volume yang berbeda pada masing-masing bagian. Ikan pada setiap bagian tersebut dipisahkan menjadi 3 bagian lagi dan ditimbang. Volume SDBS yang ditambahkan pada masing-masing bagian adalah sebanyak 0,$400 ; 2,40$ dan 6,00 $\mathrm{mL}$.

\section{Isolasi SDBS dari tubuh ikan}

Isolasi SDBS dilakukan dengan menggunakan ekstraksi Soxhlet. Sampel ikan dibekukan selama 24 jam, kemudian dimasukkan ke dalam freeze dryer sampai kering dan mempunyai berat yang konstan. Sampel yang telah kering dan mempunyai berat konstan tersebut ditimbang dan dihaluskan dengan menggunakan blender lalu dibungkus kertas saring. Sampel kemudian dimasukkan ke dalam kolom ekstraksi. Sampel ikan diekstraksi menggunakan metode Soxhlet menggunakan $150 \mathrm{~mL}$ n-heksana selama 9 jam pada suhu $80^{\circ} \mathrm{C}$ dan diikuti dengan metanol $150 \mathrm{~mL}$ pada suhu $80^{\circ} \mathrm{C}$ selama 6 jam. Hasil ekstraksi di evaporasi dengan alat rotary evaporator hingga metanol habis. Residu kemudian dilarutkan dalam akuabides hangat menggunakan labu ukur 100 mL. Sampel kemudian dianalisis menggunakan spektrofotometer UV-Vis dengan pereaksi AO.

\section{Proses analisis SDBS dengan spektrofotometer UV-Vis}

Proses analisis SDBS dengan spektrofotometer UV-Vis diawali dengan proses ekstraksi cair-cair. Prosesnya adalah sebagai berikut: $10,0 \mathrm{~mL}$ sampel yang mengandung SDBS tadi ditambah dengan AO dan asam asetat glasial masing-masing 100 $\mu \mathrm{L}$. Pasangan ion DBS-AO yang terbentuk lalu diekstraksi dengan menambahkan toluena 5,00 mL yang dimasukkan ke dalam corong pisah. Campuran larutan kemudian digojok 1 menit dan didiamkan 5 menit, kemudian didiamkan selama operatint time lalu fase organiknya diambil lalu diukur pada panjang gelombang maksimum. 


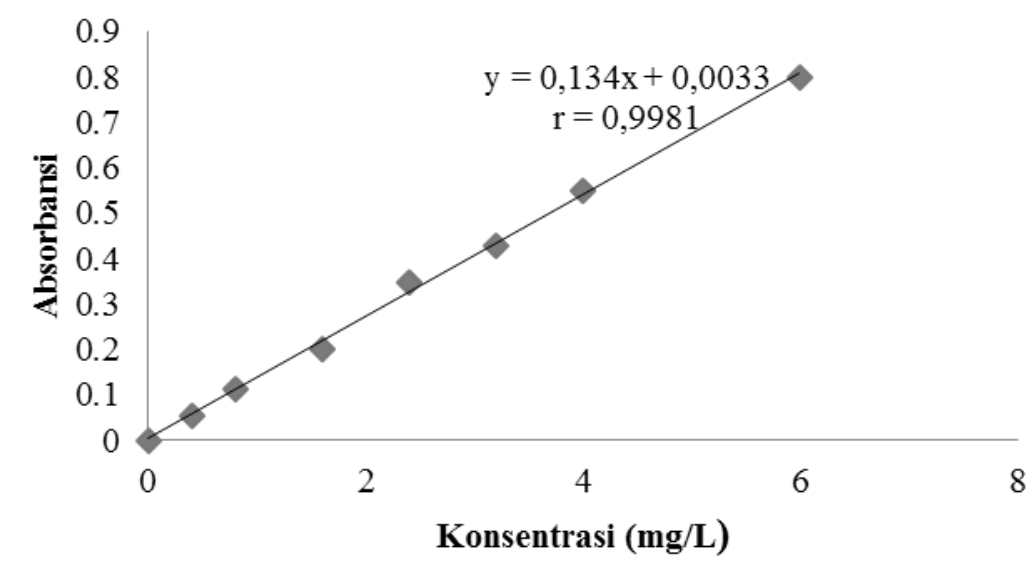

Gambar 1. Kurva Standar Larutan Surfaktan SDBS

Tabel 1. Data perhitungan presisi pada hari yang sama (intraday)

\begin{tabular}{|c|c|c|c|c|c|c|}
\hline $\begin{array}{c}\text { Konsentrasi } \\
\text { SDBS yang } \\
\text { ditambahkan } \\
(\mathrm{mg} / \mathrm{L})\end{array}$ & Replikasi & Absorbansi & $\begin{array}{l}\text { Konsentrasi } \\
\text { SDBS yang } \\
\text { terukur } \\
(\mathrm{mg} / \mathrm{L})\end{array}$ & $\begin{array}{l}\text { Konsentrasi rata- } \\
\text { rata SDBS } \\
(\mathrm{mg} / \mathrm{L})\end{array}$ & SD & $\operatorname{RSD}(\%)$ \\
\hline \multirow{4}{*}{0,4} & 1 & 0,0667 & 0,4734 & \multirow{3}{*}{0,4704} & \multirow{3}{*}{0,006} & \multirow{3}{*}{1,2674} \\
\hline & 2 & 0,0654 & 0,4636 & & & \\
\hline & 3 & 0,0669 & 0,4743 & & & \\
\hline & 1 & 0,3464 & 2,5606 & \multirow{3}{*}{2,5520} & \multirow{3}{*}{0,0091} & \multirow{3}{*}{0,3553} \\
\hline \multirow[t]{2}{*}{2,4} & 2 & 0,3447 & 2,5475 & & & \\
\hline & 3 & 0,3447 & 2,5478 & & & \\
\hline \multirow{3}{*}{6,0} & 1 & 0,8369 & 6,2209 & \multirow{3}{*}{6,2015} & \multirow{3}{*}{0,057} & \multirow{3}{*}{0,9193} \\
\hline & 2 & 0,8403 & 6,2463 & & & \\
\hline & 3 & 0,8257 & 6,1373 & & & \\
\hline
\end{tabular}

Tabel 2. Data Perhitungan Presisi di Hari yang Berbeda (interday)

\begin{tabular}{|c|c|c|c|c|c|c|}
\hline $\begin{array}{c}\text { Konsentrasi } \\
\text { SDBS yang } \\
\text { ditambahkan } \\
(\mathrm{mg} / \mathrm{L})\end{array}$ & Replikasi & Absorbansi & $\begin{array}{c}\text { Konsentrasi } \\
\text { SDBS yang } \\
\text { terukur } \\
(\mathrm{mg} / \mathrm{L})\end{array}$ & $\begin{array}{c}\text { Konsentrasi rata- } \\
\text { rata SDBS } \\
(\mathrm{mg} / \mathrm{L})\end{array}$ & SD & $\operatorname{RSD}(\%)$ \\
\hline \multirow{3}{*}{0,4} & 1 & 0,0739 & 0,5477 & \multirow{3}{*}{0,5442} & \multirow{3}{*}{0,0070} & \multirow{3}{*}{1,2819} \\
\hline & 2 & 0,0739 & 0,5361 & & & \\
\hline & 3 & 0,0737 & 0,5487 & & & \\
\hline \multirow{3}{*}{2,4} & 1 & 0,3299 & 2,3796 & \multirow{3}{*}{2,3893} & \multirow{3}{*}{0,0091} & \multirow{3}{*}{0,3795} \\
\hline & 2 & 0,3260 & 2,3974 & & & \\
\hline & 3 & 0,3249 & 2,3908 & & & \\
\hline \multirow{3}{*}{6,0} & 1 & 0,8035 & 6,0671 & \multirow{3}{*}{6,0451} & \multirow{3}{*}{0,0742} & \multirow{3}{*}{1,2268} \\
\hline & 2 & 0,8238 & 5,9624 & & & \\
\hline & 3 & 0,8191 & 6,1058 & & & \\
\hline
\end{tabular}

\section{HASIL DAN PEMBAHASAN}

Analisis SDBS dilakukan untuk menentukan akumulasi SDBS pada ikan lele yang dibudidaya secara terkontrol dan konsentrasi SDBS pada sampel ikan air tawa yang dijual di pasar di kota Yogyakarta.
Penelitian ini didahului dengan melakukan budidaya ikan lele secara terkontrol untuk menentukan besarnya akumulasi SDBS pada ikan lele. Proses analisis diawali dengan penentuan parameter validasi metode analisis. 


\section{Parameter validasi metode}

Hasil pengukuran kurva standar dapat dilihat pada Gambar 1. Harga $r$ pada kurva adalah sebesar 0,9981 , harga $\mathrm{r}$ pada analisis ini telah memenuhi kriteria reliabilitas dan dapat dikatakan linier. Suatu kurva dapat disebut linier apabila harga $r \geq 0,995$ (Harris, 2010). Nilai $r$ dari suatu kurva standar menunjukan tingkat reliabilitas dari metode tersebut, apabila harga $\mathrm{r}$ mendekati 1 maka metode tersebut mempunyai reliabilitas yang tinggi dan hasil analisis dapat diterima. Dari hasil perhitungan data absorbansi dari kurva standar, didapatkan batas deteksi atau limit of detection (LOD) sebesar $0,08 \mathrm{mg} / \mathrm{L}$ dan nilai batas kuantifikasi atau limit of quantification (LOQ) adalah sebesar 0,296 mg/L.

Penetuan presisi yang ditunjukan berdasarkan perhitungan besar relative standard deviation (RSD). Hasil perhitungan menunjukkan bahwa metode ini mempunyai presisi yang baik dengan nilai relative standard deviation (RSD) $<2 \%$ baik untuk pengukuran pada hari yang sama (intraday), maupun pada hari yang berbeda (interday). Penetuan presisi dilakukan dengan tiga kali pengulangan pada setiap konsentrasi, pemilihan konsentrasi didasarkan pada kriteria konsentrasi rendah, sedang dan tinggi. Data hasil pengukuran presisi intraday mauoun interday dapat dilihat pada Tabel 1 dan 2.

Penentuan akurasi dilakukan untuk menentukan kesuaian analit hasil analisis dengan nilai yang dapat diterima. Pada penelitian ini besarnya pengukuran harga akurasi telah sesuai dengan teori, dimana persen perolehan kembali untuk sampel kelumit adalah sebesar 80-110\%. Berdasarkan Tabel 3, besarnya nilai akurasi (persen perolehan kembali) berada pada rentang 83$107 \%$ yang menurut teori merupakan rentang dengan akurasi yang dapat diterima.

\section{Pengaruh protein dan ion pengganggu dalam analisis SDBS pada ikan}

Pada penelitian ini pengaruh protein yang diteliti diwakili sampel Bovine Serum Albumin (BSA). Ion pengganggu yang dipelajari pengaruhnya adalah ion $\mathrm{Ca}^{2+}$ dan $\mathrm{Mg}^{2+}$, pemilihan kedua ion ini didasarkan pada hasil analisis menggunakan SSA dimana isolat hasil ekstraksi Soxhlet mengandung kedua ion tersebut, yaitu $\mathrm{Ca}^{2+}$ sebesar $5,15-5,24 \mathrm{mg} / \mathrm{L}$ dan $\mathrm{Mg}^{2+}$ sebesar 1,55-1,59 mg/L. Penentuan pengaruh protein dan ion pengganggu perlu dilakukan, karena menurut Susanto dan Fahmi (2012) bagian tubuh ikan mengandung banyak matrik, diantaranya adalah protein, peptida, vitamin, mineral, air, lemak dan abu.

Tabel 3. Data Perhitungan Akurasi

\begin{tabular}{|c|c|c|c|c|c|c|}
\hline Analit & $\begin{array}{c}\text { Konsentrasi } \\
\text { SDBS yang } \\
\text { ditambahakan } \\
(\mathrm{Ca}) \\
(\mathrm{mg} / \mathrm{L})\end{array}$ & Absorbansi & $\begin{array}{c}\text { Konsentrasi } \\
\text { total sampel } \\
(\mathrm{Cs}) \\
(\mathrm{mg} / \mathrm{L})\end{array}$ & $\begin{array}{c}\text { Konsentrasi } \\
\text { sampel } \\
\text { tanpa analit } \\
(\mathrm{Cb}) \\
(\mathrm{mg} / \mathrm{L}) \\
\end{array}$ & $\mathrm{Cs}-\mathrm{Cb}$ & Akurasi (\%) \\
\hline 1 & & 0,0681 & 0,4836 & & 0,3351 & 84 \\
\hline 2 & 0,4 & 0,0701 & 0,4985 & & 0,3500 & 88 \\
\hline 3 & & 0,0607 & 0,4284 & & 0,4284 & 107 \\
\hline 1 & & 0,3132 & 2,3127 & & 2,3127 & 96 \\
\hline 2 & 2,4 & 0,2799 & 2,0642 & 0,1485 & 2,0642 & 86 \\
\hline 3 & & 0,3206 & 2,3679 & & 2,3679 & 99 \\
\hline 1 & & 0,7715 & 5,7328 & & 5,7328 & 96 \\
\hline 2 & 6,0 & 0,6714 & 4,9858 & & 4,9858 & 83 \\
\hline 3 & & 0,7025 & 5,2179 & & 5,2179 & 87 \\
\hline
\end{tabular}


Adanya ion $\mathrm{Ca}^{2+}$ tidak mengganggu analisis SDBS hingga konsentrasi $12,0 \mathrm{mg} / \mathrm{L}$, pada konsentrasi lebih dari $12,0 \mathrm{mg} / \mathrm{L}$ adanya ion $\mathrm{Ca}^{2+}$ dapat mengganggu proses analisis SDBS. Adanya gangguan ion diketahui berdasarkan perubahan absorbansi sampel sebesar 5\%. Ion $\mathrm{Mg}^{2+}$ dapat mengganggu proses analisis sampel apabila konsentrasi ion $\mathrm{Mg}^{2+}$ dalam sampel lebih dari $6,00 \mathrm{mg} / \mathrm{L}$. Pada hasil analisis dengan SSA, konsentrasi ion $\mathrm{Ca}^{2+}$ dalam ekstrak ikan sampel kurang dari $12,0 \mathrm{mg} / \mathrm{L}$ dan ion $\mathrm{Mg}^{2+}$ juga kurang dari 6,00 $\mathrm{mg} / \mathrm{L}$, sehingga adanya ion $\mathrm{Ca}^{2+}$ dan $\mathrm{Mg}^{2+}$ tidak berpengaruh terhadap analisis SDBS.

Berdasarkan hasil analisis, BSA dapat berpengaruh terhadap proses analisis SDBS dengan alat spektrofotometer UV-Vis. Hal ini ditunjukkan oleh hasil analisis dengan spektrofotometer UV-Vis dimana dengan adanya konsentrasi BSA yang semakin besar dapat menurunkan besarnya absorbansi dari pasangan ion DBS-AO dengan konsentrasi SDBS yang dibuat tetap yaitu $2,40 \mathrm{mg} / \mathrm{L}$. Penurunan absorbansi ini disebabkan pada saat DBS membentuk misel protein BSA berinteraksi dengan DBS dengan melingkupinya, sehingga gugus hidrofilik dari DBS tidak dapat membentuk pasangan ion dengan pereaksi AO (Otzen, 2011; Turro dan Lei, 1995). Proses ekstraksi Soxhlet dengan suhu tinggi dan waktu yang lama dapat meminimalisir pengaruh protein pada proses analisis. Penggunaan suhu yang tinggi pada ekstraksi Soxhlet dapat menyebabkan protein terdenaturasi (Dias et al., 2010)

\section{Persiapan sampel}

Persiapan sampel ikan dilakukan melalui beberapa tahapan sebelum akhirnya dianalisis. Tahap awal dimulai dengan budidaya ikan lele yang dilakukan di kolam fiber selama tiga bulan. Sebelum penyebaran bibit ikan lele, kolam fiber dipersiapkan terlebih dahulu. Air pada kolam didiamkan selama 5 hari sebelum ditaburi benih ikan lele. Tujuannya agar air tenang dan ikan lebih mudah beradaptasi di dalam kolam tersebut. Bibit ikan dibiarkan beradaptasi selama 5 hari sebelum air kolam diberi surfaktan. Tujuan adaptasi ini adalah supaya ikan lele tidak mengalami stress dan mudah mati ketika air dicampur dengan surfaktan. Air yang berada di kolam fiber kemudian diganti setiap 5 hari sekali. Penggantian air bertujuan agar konsentrasi surfaktan yang berada di kolam ikan selalu tetap. Konsentrasi surfaktan yang dipaparkan pada masing-masing kolam adalah sebesar 0; 2,5; 5; 10 dan 15 mg/L. Konsentrasi surfaktan yang dikontrol ini dilakukan untuk mengetahui pengaruh konsentrasi surfaktan terhadap akumulasi yang terjadi pada ikan lele. Budidaya dilakukan selama tiga bulan, lama budidaya disesuaikan dengan lama budidaya ikan lele yang telah dilakukan oleh Khairuman et al. (2008). Pengambilan sampel dilakukan tiga kali pengambilan pada masingmasing kolam secara acak. Hal ini dilakukan agar validitas data yang dihasilkan dapat terjamin. Ikan diambil sebanyak dua ekor setiap kali pengambilan pada masing-masing kolam.

\section{Preparasi sampel}

Proses analisis surfaktan SDBS diawali dengan preparasi sampel. Sampel ikan yang telah diambil dari kolam perikanan kemudian dipotong kecil-kecil lalu diblender hingga halus, sampel diblender untuk memudahkan proses preparasi. Sampel yang telah halus dimasukkan ke dalam freezer selama 24 jam hingga beku. Tujuan pembekuan adalah agar kandungan airnya membeku dan memudahkan proses freeze dry. Sampel beku lalu dimasukkan ke dalam alat freeze dryer hingga beratnya konstan. Penggunaan alat freeze dry dilakukan untuk menghilangkan air di dalam daging ikan lele yang telah beku. Pengeringan dengan menggunakan freeze dry dilakukan karena adanya kandungan air pada sampel dapat mengganggu proses isolasi SDBS melalui proses ekstraksi Soxhlet.

Sampel kering diblender ulang dan dibungkus kertas saring lalu diekstraksi dengan menggunakan alat Soxhlet. Ekstraksi dengan menggunakan alat Soxhlet ini dilakukan untuk mengisolasi SDBS dari sampel ikan. Ekstraksi dengan alat Soxhlet ini termasuk ke dalam jenis ekstraksi padat cair. Proses ekstraksi Soxhlet ini mempunyai dua tahapan. Prosedur isolasi SDBS pada 
penelitian ini didasarkan pada metode isolasi yang telah dikembangkan dan dioptimasi oleh (Sáez et al., 2000). Tahap pertama adalah ekstraksi selama 9 jam menggunakan pelarut n-heksana. Pelarut n-heksana merupakan pelarut non-polar, sehingga n-heksana mampu menghilangkan zat-zat yang dapat mengganggu analisis surfaktan yang berupa senyawa non-polar. Salah satu zat yang dihilangkan dalam proses ini adalah lemak (Versteeg dan Rawlings, 2003). Tahap kedua adalah ekstraksi dengan menggunakan pelarut metanol. Ekstraksi dengan menggunakan metanol bertujuan untuk mengisolasi SDBS dari sampel ikan, metanol adalah pelarut semi polar yang mampu melarutkan SDBS.

Tahap pertama dari proses ekstraksi Soxhlet ini menghasilkan larutan n-heksana yang sudah mengandung zat-zat pengganggu. Adanya zat pengganggu seperti lemak dapat diamati dari ekstrak yang berwarna kuning dan keruh. Ekstrak yang berwarna kuning ini apabila didiamkan akan menggumpal. Gumpalan ini adalah lemak dan senyawa nonpolar yang terdapat di dalam sampel ikan. Tahap kedua menghasilkan ekstrak metanol yang berwarna kuning kemerahan yang jernih. Larutan tidak mengalami penggumpalan meskipun lama didiamkan. Ekstrak metanol kemudian dievaporasi, namun apabila tidak segera dievaporasi, ekstrak metanol harus dimasukkan ke dalam lemari pendingin. Penyimpanan di lemari pendinging bertujuan untuk mencegah kerusakan sampel.

Proses selanjutnya adalah melakukan evaporasi terhadap ekstrak metanol yang telah diperoleh. Ekstrak metanol dievaporasi hingga pelarut metanol yang ada di dalamnya hilang dan hanya menyisakan analit yang berupa surfaktan DBS. Analit yang berupa surfaktan SDBS yang didapat melalui evaporasi dilarutkan ke dalam $100 \mathrm{~mL}$ akuabides panas. Larutan sampel SDBS disimpan di lemari pendingin.

\section{Analisis SDBS dalam sampel ikan lele budidaya dan penentuan faktor biokonsentrasi (BCF)}

Metode analisis yang digunakan dalam penelitian ini telah melalui tahap validasi metode. Oleh karena itu metode ini dapat diaplikasikan untuk analisis SDBS dalam sampel ikan lele dan ikan lainnya. Data hasil analisis SDBS pada ikan lele yang dibudidayakan dalam kolam perikanan dengan paparan SDBS dapat dilihat pada Tabel 4.

Tabel 4. Konsentrasi SDBS pada Ikan Lele dengan Paparan SDBS

\begin{tabular}{cccccc}
\hline $\begin{array}{c}\text { Paparan } \\
\text { SDBS }\end{array}$ & Replikasi & $\begin{array}{c}\text { Konsentrasi } \\
\text { terbaca }(\mathrm{mg} / \mathrm{L})\end{array}$ & $\begin{array}{c}\text { Konsentrasi pada } \\
\text { ikan }(\mathrm{mg} / \mathrm{g})\end{array}$ & $\begin{array}{c}\text { Konsentrasi pada } \\
\text { ikan }(\mathrm{mg} / \mathrm{kg})\end{array}$ & SD \\
\hline $2,5 \mathrm{mg} / \mathrm{L}$ & I & 1,936 & 0,0044 & 4,370 & \\
& II & 1,826 & 0,0025 & 2,520 & $\pm 0,9365$ \\
$5 \mathrm{mg} / \mathrm{L}$ & III & 1,750 & 0,0032 & 3,192 & \\
& I & 3,071 & 0,0067 & 6,722 & $\pm 0,4061$ \\
& II & 2,890 & 0,0074 & 7,366 & \\
$10 \mathrm{mg} / \mathrm{L}$ & III & 3,057 & 0,0066 & 6,614 & \\
& I & 4,243 & 0,0092 & 9,180 & \\
& II & 4,292 & 0,0078 & 7,754 & $\pm 0,7947$ \\
$15 \mathrm{mg} / \mathrm{L}$ & III & 2,660 & 0,0079 & 7,859 & \\
& I & 4,598 & 0,0078 & 7,839 & 8,274 \\
\hline
\end{tabular}


Tabel 5. Nilai BCF Surfaktan Anionik SDBS dalam Ikan Lele

\begin{tabular}{|c|c|c|c|c|c|}
\hline Sampel & Variasi & $\begin{array}{l}\text { Konsentrasi pada } \\
\text { ikan }(\mathrm{mg} / \mathrm{kg})\end{array}$ & $\begin{array}{l}\text { Konsentrasi rata- } \\
\text { rata pada ikan } \\
(\mathrm{mg} / \mathrm{kg})\end{array}$ & $\begin{array}{c}\text { Konsentrasi pada } \\
\text { air }(\mathrm{mg} / \mathrm{L})\end{array}$ & $\mathrm{BCF}(\mathrm{L} / \mathrm{kg})$ \\
\hline \multirow{3}{*}{$2,5 \mathrm{mg} / \mathrm{L}$} & I & 4,370 & \multirow{3}{*}{3,361} & \multirow{3}{*}{2,5} & \multirow{3}{*}{1,344} \\
\hline & II & 2,520 & & & \\
\hline & III & 3,192 & & & \\
\hline \multirow{3}{*}{$5 \mathrm{mg} / \mathrm{L}$} & I & 6,722 & \multirow{3}{*}{6,901} & \multirow{3}{*}{5} & \multirow{3}{*}{1,380} \\
\hline & II & 7,366 & & & \\
\hline & III & 6,614 & & & \\
\hline \multirow{3}{*}{$10 \mathrm{mg} / \mathrm{L}$} & I & 9,180 & \multirow{3}{*}{8,260} & \multirow{3}{*}{10} & \multirow{3}{*}{0,826} \\
\hline & II & 7,754 & & & \\
\hline & III & 7,859 & & & \\
\hline \multirow{3}{*}{$15 \mathrm{mg} / \mathrm{L}$} & I & 7,839 & \multirow{3}{*}{8,018} & \multirow{3}{*}{15} & \multirow{3}{*}{0,535} \\
\hline & II & 8,274 & & & \\
\hline & III & 7,940 & & & \\
\hline
\end{tabular}

Dari hasil analisis pada Tabel 4 dapat dilihat bahwa sampel ikan lele yang dibudidayakan dengan paparan SDBS pada konsentrasi tertentu di kolam perikanan memberikan absorbansi yang cukup besar. Ikan lele dapat mengakumulasi SDBS yang terdapat pada lingkungan hidupnya. Semakin tinggi konsentrasi surfaktan yang dipaparkan maka semakin tinggi konsentrasi SDBS yang ada di dalam tubuh ikan. Hal ini sesuai dengan penelitian Versteeg dan Rawlings (2003) yang menunjukkan bahwa semakin tinggi paparan surfaktan, maka akumulasi surfaktan pada tubuh ikan juga semakin tinggi. Dari Tabel 4 dapat dilihat bahwa terdapat perbedaan konsentrasi SDBS pada ikan lele yang diberikan paparan dengan konsentrasi yang sama. Perbedaan konsentrasi ini karena kondisi fisik dari ikan lele itu sendiri. Perbedaan kondisi tubuh ikan lele tersebut berpengaruh terhadap kemampuan ikan lele dalam mengakumulasi surfaktan.

Faktor biokonsentrasi merupakan besarnya substansi terlarut yang diambil secara selektif. Besarnya nilai faktor biokonsentrasi dapat digunakan untuk mengetahui besarnya bioakumulasi SDBS yang terdapat pada ikan lele. Bioakumulasi dapat digunakan untuk mengetahui kemampuan ikan lele dalam mengakumulasi
SDBS. Nilai faktor biokonsentrasi dapat dihitung dengan menggunakan persamaan $\mathrm{BCF}=\frac{\mathrm{k}_{\mathrm{u}}}{\mathrm{k}_{\mathrm{e}}}=\frac{\left\lfloor\mathrm{X}_{(\mathrm{lemak})}\right\rfloor}{\left[\mathrm{X}_{(\mathrm{aq})}\right]}$ (Manahan, 2003).

Dari data pada Tabel 5 diketahui bahwa nilai BCF dari ikan lele akan semakin turun ketika paparan DBS dalam air semakin tinggi. Hasil tersebut sesuai dengan penelitian Versteeg dan Rawlings (2003) diketahui bahwa nilai bioconcentration factors (BCF) akan mengalami penurunan apabila konsentrasi paparan surfaktan anionik meningkat. Penurunan nilai BCF pada ikan lele ini karena kemampuan ikan lele dalam mengakumulasi surfaktan terbatas, sehingga jumlah SDBS yang terdapat di ikan lele juga terbatas. Jadi karena kemampuan akumulasi ikan lele terbatas, apabila konsentrasi SDBS pada ikan dibandingkan dengan konsentrasi SDBS di air budidaya akan mengalami penurunan jika konsentrasi SDBS pada air meningkat. Pada Tabel 5 tersebut terdapat anomali pada konsentrasi $2,5 \mathrm{mg} / \mathrm{L}$ dan 5 $\mathrm{mg} / \mathrm{L}$, dimana $\mathrm{BCF}$ pada konsentrasi $5 \mathrm{mg} / \mathrm{L}$ lebih besar dibanding $2,5 \mathrm{mg} / \mathrm{L}$. Anomali yang terjadi kemungkinan dipengaruhi oleh kondisi fisik ikan, dan kandungan lemak pada ikan yang dianalisis. 


\section{Analisis SDBS dalam Sampel Pasar}

Pada penelitian ini juga dilakukan analisis SDBS pada sampel ikan di pasaran. Analisis SDBS menggunakan sampel ikan lele, gurame dan nila merah. Pengambilan sampel dilakukan secara acak dari pasar dan supermarket di kota Yogyakarta. Sampel diambil secara acak, satu jenis sampel ikan di ambil di setiap pasar dan supermarket. Analisis sampel ikan yang terdapat di pasaran dilakukan untuk mengetahui apakah sampel ikan di pasaran mengandung surfaktan SDBS atau tidak. Selain itu juga memberikan informasi kepada masyarakat tentang keamanan ikan air tawar yang dijual di pasar. Hasil analisis sampel ikan yang diperoleh dari pasar dapat dilihat pada Tabel 6.

Berdasarkan data pada Tabel 6 dapat dilihat bahwa ternyata sampel ikan yang diperoleh di pasaran memberikan serapan. Ini dapat diartikan bahwa sampel ikan di pasaran mengandung SDBS. Sampel yang mengandung SDBS tidak hanya ikan lele saja tetapi juga pada ikan gurame dan nila merah. Adanya kandungan SDBS pada ikan di pasaran kemungkinan karena air yang digunakan dalam budidaya ikan air tawar tersebut mengandung surfaktan SDBS. Kandungan surfaktan pada air kolam budidaya ikan dapat berasal dari limbah rumah tangga.

Konsentrasi SDBS terdapat pada ikan nila merah lebih tinggi dari pada ikan lele. Hal ini disebabkan lama budidaya ikan nila merah hingga dapat dikonsumsi adalah 4-5 bulan, sedangkan ikan lele hanya 2,5-3 bulan. Lama paparan senyawa xenobiotic di dalam lingkungan hidup ikan akan berpengaruh terhadap akumulasi senyawa tersebut dalam ikan (Vinodhini dan Narayanan, 2008). Ikan gurame mempunyai lama budidaya sekitar 4 bulan, akan tetapi kandungan lemak pada ikan gurame hanya 2,20-2,79 \% (Zakaria, 2008), lebih rendah dibandingkan dengan ikan lele sebesar 4,8\% (Ubadillah dan Hersoelistyorini, 2010), serta ikan nila merah sebesar $4,1 \%$ (Hasibuan dan Soewarsono, 1999). Konsentrasi SDBS dalam ikan nila merah lebih tinggi dibandingkan ikan lele, karena waktu budidayanya lebih lama meskipun kadar lemaknya sedikit lebih rendah. Sehingga dapat disimpulkan bahwa besarnya konsentrasi SDBS dalam tubuh ikan dipengaruhi oleh lama paparan SDBS dalam tubuh ikan dan kandungan lemak dalam tubuh ikan tersebut.

\section{Analisis SDBS dalam Sampel Pasar}

Pada penelitian ini juga dilakukan analisis SDBS pada sampel ikan di pasaran. Analisis SDBS menggunakan sampel ikan lele, gurame dan nila merah. Pengambilan sampel dilakukan secara acak dari pasar dan supermarket di kota Yogyakarta. Sampel diambil secara acak, satu jenis sampel ikan di ambil di setiap pasar dan supermarket. Analisis sampel ikan yang terdapat di pasaran dilakukan untuk mengetahui apakah sampel ikan di pasaran mengandung surfaktan SDBS atau tidak. Selain itu juga memberikan informasi kepada masyarakat tentang keamanan ikan air tawar yang dijual di pasar. Hasil analisis sampel ikan yang diperoleh dari pasar dapat dilihat pada Tabel 6.

Tabel 6. Konsentrasi SDBS pada Ikan di Pasaran

\begin{tabular}{ccc}
\hline Paparan surfaktan & Pasar & Konsentrasi pada ikan DBS/ikan (mg/g) \\
\hline \multirow{2}{*}{ Gurame } & S & 0,0008 \\
& G & 0,0024 \\
& C & 0,0026 \\
\hline \multirow{2}{*}{ Lele } & K & 0,0029 \\
& G & 0,0012 \\
Nila merah & C & 0,0018 \\
& S & 0,0077 \\
& G & 0,0055 \\
& C & 0,0038 \\
\hline
\end{tabular}

Keterangan: S, G, C merupakan kode pasar. 
Berdasarkan data pada Tabel 6 dapat dilihat bahwa ternyata sampel ikan yang diperoleh di pasaran memberikan serapan. Ini dapat diartikan bahwa sampel ikan di pasaran mengandung SDBS. Sampel yang mengandung SDBS tidak hanya ikan lele saja tetapi juga pada ikan gurame dan nila merah. Adanya kandungan SDBS pada ikan di pasaran kemungkinan karena air yang digunakan dalam budidaya ikan air tawar tersebut mengandung surfaktan SDBS. Kandungan surfaktan pada air kolam budidaya ikan dapat berasal dari limbah rumah tangga.

Konsentrasi SDBS terdapat pada ikan nila merah lebih tinggi dari pada ikan lele. Hal ini disebabkan lama budidaya ikan nila merah hingga dapat dikonsumsi adalah 4-5 bulan, sedangkan ikan lele hanya 2,5-3 bulan. Lama paparan senyawa xenobiotic di dalam lingkungan hidup ikan akan berpengaruh terhadap akumulasi senyawa tersebut dalam ikan (Vinodhini dan Narayanan, 2008). Ikan gurame mempunyai lama budidaya sekitar 4 bulan, akan tetapi kandungan lemak pada ikan gurame hanya 2,20-2,79 \% (Zakaria, 2008), lebih rendah dibandingkan dengan ikan lele sebesar 4,8\% (Ubadillah dan Hersoelistyorini, 2010), serta ikan nila merah sebesar $4,1 \%$ (Hasibuan dan Soewarsono, 1999). Konsentrasi SDBS dalam ikan nila merah lebih tinggi dibandingkan ikan lele, karena waktu budidayanya lebih lama meskipun kadar lemaknya sedikit lebih rendah. Sehingga dapat disimpulkan bahwa besarnya konsentrasi SDBS dalam tubuh ikan dipengaruhi oleh lama paparan SDBS dalam tubuh ikan dan kandungan lemak dalam tubuh ikan tersebut.

\section{KESIMPULAN}

Protein Bovine Serum Albumin (BSA) menurunkan absorbansi sampel, interferensi ion $\mathrm{Ca}^{2+}$ terjadi pada konsentrasi lebih dari $12,0 \mathrm{mg} / \mathrm{L}$ dan interferensi ion $\mathrm{Mg}^{2+}$ terjadi pada konsentrasi lebih dari $6,00 \mathrm{mg} / \mathrm{L}$. Metode analisis SDBS secara spektrofotometri UVVis dengan pereaksi AO memberikan koefisien korelasi sebesar 0,9981, batas deteksi sebesar 0,089 mg/L, batas kuantifikasi sebesar 0,0296 mg/L, RSD < 2\% dan \% perolehan kembali sebesar $83-107 \%$. Semakin besar paparan surfaktan meningkatkan konsentrasi SDBS dalam ikan juga semakin besar dan nilai BCF turun. Hasil analisis sampel menunjukkan bahwa ikan lele dan jenis ikan air tawar lain mampu mengakumulasi surfaktan SDBS. Konsentrasi SDBS mampu dibaca oleh alat. Konsentrasi SDBS dalam ikan lele pasar antara 0,0012$0,0029 \mathrm{mg} / \mathrm{g}$, ikan nila sebesar $0,0038-0,0077$ $\mathrm{mg} / \mathrm{g}$ dan ikan gurame sebesar 0,0008-0,0026 $\mathrm{mg} / \mathrm{g}$. Adanya surfaktan SDBS pada sampel ikan menunjukkan bahwa ikan tersebut hidup di lingkungan yang tercemar surfaktan SDBS.

\section{UCAPAN TERIMAKASIH}

Penulis mengucapkan terimakasih kepada Ibu Adhitasari Suratman dan Bapak Roto yang telah memberikan arahan dan dukungan pada penelitian ini.

\section{DAFTAR PUSTAKA}

Ardi, I., 2013. Budidaya ikan sistem keramba jaring apung guna menjaga keberlanjutan lingkungan perairan waduk cirata. Media Akuakultur, 8 (1), 23-29.

Arendorf, J., Bojczuk, K., Sims, E., Menkveld, R., Golsteijn, L., Gaasbeek, A., Boyano, A., Medyna, G., dan Kaps, R., 2014. Revision of European Ecolabel Criteria for Laundry Detergents. Institute for Prospective Technological Studies (IPTS).

Britton, L.N., 1998. Surfactants and the Environment. Journal of Surfactants and Detergents, 1 (1), 109-117.

Coelho, S. dan Rocha, O., 2010. Assessment of the Potential Toxicity of a Linear Alkylbenzene Sulfonate ( LAS ) to Freshwater Animal Life by Means of Cladoceran Bioassays. Ecotoxicology, 19, 812-818.

Dias, C.L., Ala-Nissila, T., Wong-ekkabut, J., Vattulainen, I., Grant, M., dan Karttunen, M., 2010. The Hydrophobic Effect and Its Role in Cold Denaturation. Cryobiology, 60 (1), 91-99.

Dietrich, A.M., 2015. EPA Secondary 
Maximum Contaminant Levels: A Strategy for Drinking Water Quality and Consumer Acceptability. Philadelphia: Philadelphia Water Departement.

Gassel, M., Harwani, S., Park, J., dan Jahn, A., 2013. Detection of Nonylphenol and Persistent Organic Pollutants in Fish from the North Pacific Central Gyre. Marine Pollution Bulletin, 73 (1), 231-242.

Graziano, G., 1999. Hydrophobicity of Benzene. Biophysical Chemistry, 82 (1), 69-79.

Harris, D.C., 2010. Quantitative Chemical Analysis. Eight edition. New York: W. H. Freeman and Company All.

Hasibuan, A.P. dan Soewarsono, H., 1999. Pengaruh Pemberian Pakan yang mengandung Testis Sapi pada Pengalihan Jenis Kelamin (Sex-Reversal) Ikan Nila Merah (Oreochromis sp.). Penelitian dan Pengembangan Aplikasi Isotop dan Radiasi, (7), 353-357.

Indradjaja, D.D., 2010. Indonesian Aquaculture Report 2010. Jakarta: USDA Foreign Agricultural Service.

Manahan, Stanley E., 2003. Toxixological Chemistry and Biochemistry. Washington, D.C: CRC Press LLC.

Muhamat dan Hidayaturrahman, 2017. Kematian Ikan Nila pada Budi Daya Keramba Jaring Apung di Desa Aranio dan Tiwingan Lama Kabupaten Banjar, Kalimantan Selatan. In: Prossiding Seminar Nasional Masyarakat Biodiversitas Indonesia. 28-32.

Muzakar, K., 2016. Analisis Natrium Dodesilbenzena Sulfonat dalam Ikan Lele secara Maserasi dan Spektrofotometri UV-Vis menggunakan Metilen Biru. Tesis. Jurusan Kimia FMIPA UGM. Yogyakarta.

Otzen, D., 2011. Protein-Surfactant Interactions: A Tale of Many States. Biochimica et Biophysica Acta - Proteins and Proteomics, 1814 (5), 562-591.

Rust, D. dan Wildes, S., 2008. A Market Opportunity Study Update. Midland, MI:
OmniTech International Ltd.

Sáez, M., León, V.M., Gómez-Parra, a., dan González-Mazo, E., 2000. Extraction and Isolation of Linear Alkylbenzene Sulfonates and Their Intermediate Metabolites from Various Marine Organisms. Journal of Chromatography A, 889 (1-2), 99-104.

Schmitt, T.M., 2001. Analysis of Surfactant. Second edition. New York: Marcel Dekker Inc.

Susanto, E. dan Fahmi, A S., 2012. Senyawa Fungsional dari Ikan : Aplikasinya dalam Pangan. Jurnal Aplikasi Teknologi Pangan, 1 (4), 95-102.

Tolls, J., Haller, M., dan Sijm, D.T.H.M., 1999. Extraction and Isolation of Linear Alcohol Ethoxylates from Fish. Journal of Chromatography A, 839 (1-2), 109117.

Turro, N.J. dan Lei, X.-G., 1995. Spectroscopic Probe Analysis of ProteinSurfactant Interactions: the BSA/SDS system. Langmuir, 5 (10), 2525-2533.

Ubadillah, A. dan Hersoelistyorini, W., 2010. Kadar Protein dan Sifat Organoleptik Nugget Rajungan dengan Substitusi Ikan Lele ( Clarias gariepinus ). Jurnal Pangan dan Gizi, 1 (2).

Versteeg, D.J. dan Rawlings, J.M., 2003. Bioconcentration and Toxicity of Dodecylbenzene Sulfonate $\left(\mathrm{C}_{12} \mathrm{LAS}\right)$ to Aquatic Organisms Exposed in Experimental Streams. Archives of Environmental Contamination and Toxicology, 44 (2), 237-246.

Vinodhini, R. dan Narayanan, M., 2008. Bioaccumulation of Heavy Metals in Organs of Fresh Water Fish Cyprinus carpio (Common carp), International Journal of Environmental Science and Technology, 5 (2), 179-182.

Zakaria, R., 2008. Kemunduran Mutu Ikan Gurami ( Osphronemus gouramy ) Pasca Panen pada Penyimpanan Suhu Chilling. Program Studi Teknologi Hasil Perikanan, IPB, Bogor. 